DOI: https://doi.org/10.38047/rct.v9i1.4061

\title{
TRABALHISMO, POPULISMO E DEMOCRACIA NA AMÉRICA LATINA.
}

\section{César Augusto Bubolz Queirós*}

Diante de um quadro político marcado pelo avanço de uma onda conservadora e por sucessivos ataques à democracia, não apenas no Brasil, mas também pelo mundo afora, propusemos um dossiê intitulado "Trabalhismo, Populismo e Democracia na América Latina". O objetivo central foi buscar subsídios para compreender a conjuntura política atual e a crise radical das instituições democráticas brasileiras, fazendo uma reflexão sobre os fenômenos do Populismo e do Trabalhismo bem como sobre as experiências democráticas nesses países.

Para iniciar essa discussão, apresentamos o artigo A flexibilização da legislação trabalhista brasileira: a redução dos direitos garantidos pela Consolidação das Leis do Trabalho ao longo do tempo, de Alisson Droppa. Nesse trabalho, o autor busca fazer uma relação entre as modificações ocorridas na Consolidação das Leis do Trabalho a partir do golpe civil-militar de 1964, apresentadas como uma "primeira onda liberal" e a atual investida sobre a legislação trabalhista e a nova onda de ataques sobre os direitos sociais.

Em Da harmonia ao conflito: a Delegacia Regional do Trabalho em Alagoas (19561959), Anderson Vieira Moura se propõe a analisar atuação de Edson Falcão na Delegacia Regional do Trabalho (DRT) em Alagoas, destacando os conflitos e disputas que acabaram acarretando um desgaste de sua figura junto com os $\mathrm{O}$ autor faz uso de vasta documentação, utilizando de atas sindicais, reportagens de jornais, processos trabalhistas e até uma entrevista feita com seu primogênito.

Amaury Oliveira Pio Jr busca discutir as relações políticas que se desenvolvem no estado do Amazonas a partir da implantação da Revolução de 30 e do novo modelo sindical proposto por Getúlio Vargas. Para isso, analisa o periódico Tribuna Popular, jornal inicialmente vinculado ao Partido Trabalhista Amazonense (PTA) e que representava um importante veículo de divulgação do projeto varguista no estado. No artigo Jornal Tribuna Popular e a construção de um ideário "proto-trabalhista" no Amazonas, o autor percebe o

\footnotetext{
* Doutor em História pela Universidade Federal do Rio Grande do Sul (UFRGS). Professor do Departamento de História e do Programa de Pós-Graduação em História da Universidade Federal do Amazonas (UFAM). E-mail: cesardequeiros@gmail.com
} 
surgimento de uma proposta trabalhista em um estágio embrionário já na década de 30 no estado.

No artigo Conflitos, solidariedade e formação de classe - "nacionais" e estrangeiros nos primórdios da mineração de carvão do Brasil (1850-1950), Clarice Speranza analisa as relações entre trabalhadores brasileiros e imigrantes na construção nas minas de carvão do Sul do Brasil. Discutindo o processo de migração e sua importância para o o desenvolvimento das minas de carvão, destaca ainda a resistência desses trabalhadores, suas formas de organização e a tensão percebida entre uma identidade de ofício calcada na coesão e na solidariedade e a existência de espaços de segregação entre os trabalhadores.

Cremos que esse seja um momento extremamente apropriado para discutir temas como as investidas sobre a legislação trabalhista, os ataques sobre os direitos sociais e as estrategias de resistência e organização dos trabalhadores. Que a leitura dos artigos do dossiê possa contribuir para o debate e a reflexão sobre o tema. Agradecendo a excelente contribuição dos autores, desejamos uma boa leitura. 